\title{
FAKTOR PERSALINAN SECSIO CAESAREA DI RUMAH SAKIT IMANUEL BANDAR LAMPUNG
}

\author{
Marlina \\ Jurusan Kebidanan Poltekkes Tanjungkarang \\ Email: marlinanturnip@yahoo.com
}

\begin{abstract}
Factor of Sectio Caesarea in Immanuel Hospital Bandar Lampung. The number of mother's death in developing country is 230/100.000 alive giving birth where as in developed country is $16 / 100.000$ alive giving birth. The number of mother's death recently also high enough in demografi research result and Indonesian healthy 2013 shows that the number of mother's death increase sharply compare the research which is done in 2007. The research in 2007 can 228/100.000 alive giving birth where as the research in 2013 AKI increase become 359/100.000 alive giving birth. In 2010 the mother's death increase become 145 cases, in 2011 there is 122 cases, in 2012 the mother's death increase again note 144 death cases. In 2013 based on the report from district shows that all mother's death cases is 146 cases. The factors which relationship with section caesaria childbirth in Immanuel Hospital Bandar Lampung 2014. Method: In this research the writer uses analytic it is the research to get the accurate description from problem characteristic to classify a data and taking data which relate with good number which is gotten for measuring or value from a data which is gotten by cross sectional research planning. Result: There is a significant relationship between mother's age, KPD, Gravida, Fetus weight and plasenta position with SC giving birth and there is no relationship significantly between pregnancy distance and fetus position with SC childbirth.
\end{abstract}

Keywords: Sectio caesarea, Mother factor, Fetus factor

\begin{abstract}
Abstrak: Faktor Persalinan Secsio Caesarea di Rumah Sakit Imanuel Bandar Lampung. Angka kematian ibu di negara berkembang adalah 230/100.000 kelahiran hidup sedangkan di negara maju yaitu 16/100.000 kelahiran hidup. Angka kematian ibu di Indonesia saat ini juga cukup tinggi pada hasil penelitian demografi dan kesehatan indonesia tahun 2013 menunjukkan bahwa angka kematian ibu meningkat tajam dibanding penelitian yang dilakukan pada tahun 2007. Penelitian tahun 2007 dapat 228/100.000 kelahiran hidup sedangkan pada penelitian tahun 2013 AKI meningkat menjadi 359/100.000 kelahiran hidup. Pada tahun 2010 kematian ibu meningkat menjadi 145 kasus, tahun 2011 terdapat 122 kasus, tahun 2012 kematian ibu kembali mengalami peningkatan tercatat sebesar 144 kasus kematian, tahun 2013 berdasarkan laporan dari kabupaten terlihat bahwa kasus kematian ibu seluruhnya adalah 146 kasus. Tujuan Penelitian diketahui faktor-faktor yang berhubungan dengan Persalinan Secsio Caesarea di Rumah Sakit Immanuel Bandar Lampung Tahun 2014. Metode Penelitian dalam penelitian ini penulis menggunakan jenis penelitian analitik, merupakan jenis penelitian untuk mendapatkan gambaran akurat dari karakteristik masalah mengklasifikasi kan suatu data dan pengambilan data yang berhubungan dengan angka-angka baik yang diperoleh dari pengukuran maupun nilai dari suatu data yang diperoleh dengan rancangan penelitian cross sectional. Hasil penelitian ada hubungan signifikan usia ibu, KPD, paritas, berat janin dan letak plasenta dengan persalinan SC dan tidak ada hubungan signifikan antara jarak kehamilan dan letak janin dengan persalinan SC.
\end{abstract}

Kata Kunci: Sectio caesarea, Faktor ibu, Faktor janin

Kehamilan dan persalinan memerlukan proses yang fisiologis namun keadaan patologis atau komplikasi dapat saja muncul pada saat kehamilan sampai pada proses persalinan (Mocthar, 2010). Salah satu persalinan yang sering terjadi adalah persalinan dengan secsio caesarea (Prawiroharjo, 2010).

Saat ini secsio caesarea (SC) menjadi tren karena berbagai alasan dalam 20 tahun terakhir. Peningkatan ini terjadi karena berbagai alasan yaitu adanya hambatan yang dialami janin maupun ibu, namun tidak sedikit SC dilakukan karena permintaan ibu yang tidak mau melahirkan secara normal karena alasan takut (Sadiman, 2010).

Persalinan SC memiliki resiko lima kali lebih besar terjadi komplikasi dibanding persalinan normal. Faktor yang paling banyak adalah faktor anastesi, pengeluaran darah oleh ibu selama proses operasi, komplikasi penyulit, 
endometritis (radang endometrium), tromboplebitis (pembukuan darah pembuluh balik), embolisme (penyumbatan pembuluh darah) dan pemulihan bentuk dan letak rahim menjadi tidak sempurna. Komplikasi lain yang dapat bersifat ringan adalah kenaikan suhu tubuh selama beberapa hari pada masa nifas, Perencanaan kehamilan kembali juga membutuhkan waktu cukup lama. Pemulihan persalinan yang berlangsung lama sehingga ibu dapat lebih lama tinggal di rumah sakit, dan otomatis biayanya semakin mahal. Selain itu karena pemulihanya lebih lama akibat sayatan yang belum kering dan masih sakit, ibu akan menunda aktifitas lebih lama dibandingkan dengan ibu yang melahirkan alami. Termasuk hubungan seksual dan olah raga sehingga penurunan berat badan berlangsung lebih lama, selain itu seorang ibu yang mengalami SC hanya dibatasi memiliki 3 anak saja.

SC berhubungan dengan peningkatan 2 kali lipat resiko mortalitas ibu dibandingkan pada persalinan pervaginam. Kematian ibu akibat operasi SC menunjukan angka 1 per 1.000 persalinan. Menurut benson dan pernolls 2009, angka kematian pada operasi SC 40 sampai 80 tiap 100.000 kelahiran hidup. Angka ini menunjukan resiko 25 kali lebih besar dibanding persalinan pervaginam. Untuk kasus karena infeksi mempunyai angka 80 kali lebih tinggi dibandingkan persalinan pervaginam, komplikasi tindakan anastesi sekitar $10 \%$ dari angka kematian ibu (Farrel, 2010).

Dampak yang sering timbul dalam persalinan SC antara lain adalah infeksi yang banyak disebut sebagai morbilitas pasca operasi. Kurang lebih $90 \%$ dari morbilitas pasca operasi disebabkan oleh infeksi seperti: infeksi rahim, infeksi kandung kemih, infeksi usus dan infeksi luka bekas operasi. Apabila infeksi tidak segera diatasi dan dalam jangka waktu yang lama dapat menyebabkan infeksi yang berlarut sampai dengan sepsis yang dapat mengakibatkan kematian terhadap ibu. Komplikasi dapat disebabkan oleh persalinan dengan ketuban pecah dini, ibu yang menderita anemia, hipertensi, sangat gemuk, gizi yang buruk, sudah menderita infeksi sebelum melahirkan, dan dapat juga disebabkan oleh penyakit lain seperti ibu menderita penyakit diabetus melitus. Dengan pemberian antibiotik profilaksis dapat mengatasi infeksi yang terjadi (Indiarti, 2011).

Indikasi SC bisa diindikasi absolut atau relatif. Setiap keadaan yang membuat kelahiran lewat jalan lahir tidak mungkin terlaksana merupakan indikasi absolut untuk secsio abdominal. Diantaranya adalah kesempitan panggul yang sangat berat dan neoplasma yang menyumbat jalan lahir. Pada indikasi relatif, kelahiran lewat vagina bisa terlaksana tetapi keadaan adalah sedemikian rupa sehingga kelahiran lewat SC akan aman bagi ibu, anak atau pun keduanya dan bayi yang sehat dan tidak ada kesulitan.

Alasan melakukan secsio caesarea yang di rencanakan meliputi: bayi tidak dalam posisi dekat turunnya kepala dengan tanggal jatuh tempo persalinan, penyakit jantung yang dapat diperburuk karena stres kerja, infeksi yang dapat menular kebayi selama kelahiran pervaginam, ibu yang lebih dari satu bayi (kelahiran multiple), riwayat SC sebelumnya ( prawiroharjo, 2010).

Menurut Manuaba, 2005 faktor resiko terjadinya persalinan SC antara lain faktor medis: letak sungsang, perdarahan ante partum, kehamilan prematuritas, kehamilan resiko tinggi, kehamilan ganda, preeklamsi berat, kegagalan induksi dan SC berulang, permintaan SC sedangkan dari faktor non medis adalah : trauma persalinan, estetika, menentukan tanggal lahir dan rekomendasi keluarga.

WHO (World Health Organization) mengatakan standar rata-rata operasi SC sekitar $5-15 \%$, Bahkan data WHO Global survei on Maternal and perinatal Health 2011 menunjukkan 46,1\% dari seluruh kelahiran dengan SC. Menurut statistik tentang 3.509 kasus SC yang disusun oleh Peel dan Chamberlain, indikasi untuk SC adalah disproporsi janin panggul $21 \%$, gawat janin $14 \%$, Plasenta previa $11 \%$, perna secsio caesarea $11 \%$, kelainan letak janin $10 \%$, pre eklamsi dan hipertensi $7 \%$. Di China salah satu negara dengan SC meningkat draktis dari 3,4\% 1988 menjadi 39,3\% pada tahun 2010.

Di indonesia, presentasi operasi SC sekitar $5-15 \%$, dirumah sakit pemerintah sekitar $11 \%$, sementara dirumah sakit swasta bisa lebih dari $30 \%$. Menurut SDKI 2012, angka kejadian SC di Indonesia 921.000 dari 4.039 .000 persalinan atau $22,8 \%$ dari seluruh persalinan. menurut data riset kesehatan (RISKESDAS, 2013) menunjukkan SC 9,8\%, dengan proporsi tertinggi di DKI Jakarta $(19,9 \%)$ dan terendah di Sulawesi Tenggara (3,3\%).

Angka persalinan SC di provinsi Lampung tahun 2013 menurut hasil Riskesdas sekitar 4,5\%, angka kejadian secsio caesarea di Kota Bandar Lampung pada tahun 2012 adalah 3.401 dari 170.000 persalinan $(20 \%)$ dari seluruh persalinan (Dinkes Propinsi Lampung, 2012).

Hasil pra survey tanggal 1-2 November 2014, angka persalinan SC di RS Imanuel Way Halim tahun 2012 dari 100\% ibu bersalin ada 
$24,8 \%$ yang bersalin secara normal dan $75,2 \%$ dengan tindakan SC. Dengan sebagian besar berparitas primipara dan grande multipara.

Sejak tahun 2012 angka SC terus mengalami peningkatan hingga tahun 2014. Tahun 2012 terdapat 998 pra kasus, dan tahun 2013 sebanyak 1163 pra kasus dengan persalinan normal 233 dan tindakan SC 930. Tahun 2014 bulan november mencapai 342 persalinan dengan persalinan SC sebanyak 221. Proporsi penyebab persalinan SC tahun 2013 adalah ketuban pecah dini 32 kasus $(9,3 \%)$, letak sungsang 67 kasus $(19,59 \%)$, gagal induksi 25 kasus $(7,3 \%)$, riwayat secsio caesarea $58(16,9 \%)$, faktor resiko umur 12 kasus (3,5\%), paritas 19 kasus $(5,5 \%)$, jarak kehamilan $5(1,7 \%)$ PEB 2 kasus $(0,5 \%)$.

\section{METODE}

Jenis penelitian ini analitik, dengan pendekatan cross sectional, sebagai populasi semua ibu bersalin di RS Imanuel Bandar Lampung dari Januari sampai dengan Desember 2014. Sampel menggunakan total sampling, yaitu semua ibu bersalin di RS Imanuel Bandar Lampung Tahun 2014.

Pengumpulan data dengan cara observasi medical record, untuk pengumpulan data mengenai identitas ibu bersalin dengan faktorfaktor yang berhubungan dengan kejadian SC dan lembar cheklist untuk pengumpulan data mengenai ibu bersalin dengan persalinan SC.

\section{HASIL}

\section{Analisis Univariat}

Variabel independent penelitian iniadalah usia, paritas, ketuban pecah dini dan jarak kehamilan, sedangkan Variabel dependent ialah SC. Hasil penelitian sebagai berikut:

\section{a. Berdasarkan kategori Ibu}

Tabel 1. Distribusi Frekuensi Ibu Bersalin

\begin{tabular}{lcc}
\hline \multicolumn{1}{c}{ Ibu } & $\mathrm{f}$ & $(\%)$ \\
\hline Secsio Caesarea & 258 & 81,4 \\
Tidak Secsio caesarea & 59 & 18,6 \\
\hline Jumlah & 317 & 100 \\
\hline
\end{tabular}

Berdasarkan tabel 1,diketahui ternyata $81,4 \%$ ibu yang bersalin di RS Imanuel Bandar Lampung tahun 2014 adalah secara SC.

\section{b. Berdasarkan kategori usia ibu}

Tabel 2. Distribusi Frekuensi Usia Ibu

\begin{tabular}{lcc}
\hline \multicolumn{1}{c}{ Usia Ibu } & $\mathrm{f}$ & $\mathbf{( \% )}$ \\
\hline Beresiko & 72 & 22,7 \\
Tidak Beresiko & 245 & 77,3 \\
\hline Jumlah & 317 & 100 \\
\hline
\end{tabular}

Berdasarkan tabel di atas diketahui bahwa pada kategori usia ibu ternyata $22,7 \%$ merupakan usia berisiko.

\section{c. Berdasarkan Ketuban Pecah Dini}

Tabel 3. Distribusi Frekuensi Ketuban Pecah Dini

\begin{tabular}{lcc}
\hline $\begin{array}{c}\text { Ketuban Pecah Dini } \\
(\text { KPD })\end{array}$ & $\mathrm{f}$ & $\mathbf{( \% )}$ \\
\hline KPD & 63 & 19,9 \\
Tidak KPD & 254 & 80,1 \\
\hline Jumlah & 317 & 100 \\
\hline
\end{tabular}

Berdasarkan tabel 3,diketahui ternyata $19,9 \%$ ibu yang bersalin di RS Imanuel Bandar Lampung tahun 2014 mengalami KPD.

\section{d. Berdasarkan paritas}

Tabel 4. Distribusi Frekuensi Ibu menurut Paritas

\begin{tabular}{ccc}
\hline Paritas & $\mathrm{f}$ & $(\%)$ \\
\hline Primipara & 63 & 19.9 \\
Multipara & 254 & 80.1 \\
\hline Jumlah & 317 & 100 \\
\hline
\end{tabular}

Memperhatikan tabel 4, diketahui $80,1 \%$ ibu yang bersalin di RS Imanuel Bandar Lampung tahun 2014 adalah termasuk memiliki paritas multifara.

\section{e. Berdasarkan Jarak Kehamilan}

Tabel 5. Distribusi Frekuensi Ibu menurut Jarak Kehamilan

\begin{tabular}{lcc}
\hline Jarak kehamilan & $\mathrm{f}$ & $(\%)$ \\
\hline Berisiko & 181 & 57.1 \\
Tidak berisiko & 136 & 42.9 \\
\hline Jumlah & 317 & 100 \\
\hline
\end{tabular}

Berdasarkan tabel 5, diketahui ternyata $57,1 \%$ ibu yang bersalin di RS Imanuel Bandar Lampung tahun 2014 memiliki jarak kehamilan yang termasuk berisiko. 


\section{f. Berdasarkan Berat Janin}

Tabel 6. Distribusi Frekuensi Berat Janin

\begin{tabular}{ccc}
\hline Berat Janin & $\mathrm{f}$ & $\mathbf{( \% )}$ \\
\hline Berisiko & 81 & 25.6 \\
Tidak berisiko & 236 & 74.4 \\
\hline Jumlah & 317 & 100 \\
\hline
\end{tabular}

Berdasarkan tabel 6, diketahui ternyata $25,6 \%$ ibu yang bersalin di RS Imanuel Bandar Lampung tahun 2014 memiliki berat janin termasuk berisiko.

\section{g. Berdasarkan Letak Janin}

Tabel 7. Distribusi Frekuensi Letak Janin

\begin{tabular}{lcc}
\hline \multicolumn{1}{c}{ Letak Janin } & $\mathrm{f}$ & $\mathbf{( \% )}$ \\
\hline Tidak Letak Belakang Kepala & 55 & 17.4 \\
Letak Belakang Kepala & 262 & 82.6 \\
\hline Jumlah & 317 & 100 \\
\hline
\end{tabular}

Berdasarkan tabel 7, diketahui $82,6 \%$ ibu yang bersalin di RS Imanuel Bandar Lampung tahun 2014 memiliki letak janin belakang kepala.

\section{h. Berdasarkan Letak Plasenta}

Tabel 8. Distribusi Frekuensi Letak Plasenta

\begin{tabular}{lcc}
\hline \multicolumn{1}{c}{ Letak Plasenta } & $\mathrm{f}$ & $(\%)$ \\
\hline Menutup Jalan Lahir & 151 & 50,7 \\
Tdk Menutup Jalan Lahir & 92 & 49,3 \\
\hline Jumlah & 298 & 100 \\
\hline
\end{tabular}

Dengan memperhatikan tabel 8, diketahui $50,7 \%$ ibu yang bersalin di RS Imanuel Bandar Lampung tahun 2014 memiliki letak Plasenta menutup jalan lahir.

\section{Analisa Bivariat}

\section{a. Berdasarkan Usia Ibu}

Tabel 9. Hubungan Usia Ibu dengan Persalinan SC

\begin{tabular}{|c|c|c|c|c|c|c|c|c|}
\hline \multirow{3}{*}{ Usia Ibu } & \multicolumn{4}{|c|}{ Kategori Ibu } & \multicolumn{2}{|c|}{ Total } & \multirow{3}{*}{$p$ value } & \multirow{3}{*}{ OR $(95 \% \mathrm{CI})$} \\
\hline & \multicolumn{2}{|c|}{$\begin{array}{c}\text { Secsio } \\
\text { caesarea }\end{array}$} & \multicolumn{2}{|c|}{$\begin{array}{c}\text { Tidak Secsio } \\
\text { Caesarea }\end{array}$} & \multirow[t]{2}{*}{$\mathrm{n}$} & \multirow[t]{2}{*}{$\%$} & & \\
\hline & $\mathrm{n}$ & $\%$ & $\mathrm{n}$ & $\%$ & & & & \\
\hline Berisiko & 65 & $\overline{90.3}$ & 7 & 9.7 & 72 & 22.7 & 0,042 & $2,502(1,083-5,782)$ \\
\hline Tidak Berisiko & 193 & 74.8 & 51 & 21.2 & 245 & 77.3 & & \\
\hline Total & 258 & 81,4 & 59 & 18,6 & 317 & 100 & & \\
\hline
\end{tabular}

Berdasarkan tabel 9, diketahui 90,3\% usia ibu yang berisiko melahirkan secara SC dan yang tidak SC hanya $9,7 \%$.

Hasil analisis statistik diketahui terdapat hubungan yang signifikan antara usia ibu dengan persalinan $\mathrm{SC}$, dengan $\mathrm{OR}=2,502$ berarti ibu yang memiliki usia beresiko memiliki risiko bersalin dengan SC 2,502 kali lebih besar dibandingkan dengan yang usia tidak berisiko.

\section{b. Berdasarkan Ketuban Pecah Dini}

Tabel 10. Hubungan Ketuban Pecah Dini dengan Persalinan SC

\begin{tabular}{|c|c|c|c|c|c|c|c|c|}
\hline \multirow{3}{*}{$\begin{array}{l}\text { Ketuban } \\
\text { Pecah Dini }\end{array}$} & \multicolumn{4}{|c|}{ Kategori Ibu } & \multicolumn{2}{|c|}{ Total } & \multirow{3}{*}{$p$ value } & \multirow{3}{*}{ OR $(95 \% \mathrm{CI})$} \\
\hline & \multicolumn{2}{|c|}{$\begin{array}{c}\text { Secsio } \\
\text { Caesarea } \\
\end{array}$} & \multicolumn{2}{|c|}{$\begin{array}{c}\text { Tidak Secsio } \\
\text { Caesarea }\end{array}$} & \multirow[t]{2}{*}{$\mathrm{n}$} & \multirow[t]{2}{*}{$\%$} & & \\
\hline & $\mathrm{n}$ & $\%$ & $\mathrm{n}$ & $\%$ & & & & \\
\hline KPD & 64 & 24.8 & 7 & 11.9 & 71 & 22.4 & 0,048 & $2.451(1.060-5.666)$ \\
\hline Tidak KPD & 194 & 78.9 & 52 & 88.1 & 246 & 77.6 & & \\
\hline Total & 258 & 81.4 & 59 & 18.6 & 317 & 100 & & \\
\hline
\end{tabular}

Berdasarkan tabel di atas diketahui ibu yang mengalami ketuban pecah dini dan melahirkan SC $(24,8 \%)$ dan yang tidak dengan SC $11,9 \%$.
Ada hubungan yang signifikan antara ibu yang mengalami ketuban pecah dini dengan SC di RS Imanuel Bandar Lampung tahun 2014, $\mathrm{OR}=2,451$, berarti ibu yang mengalami ketuban pecah dini memilki risiko 2,451 kali lebih besar 
melahirkan secara SC dibandingkan denganh yang tidak KPD.

\section{c. Berdasarkan Paritas}

Tabel 11. Hubungan Paritas dengan Persalinan SC

\begin{tabular}{|c|c|c|c|c|c|c|c|c|}
\hline \multirow{3}{*}{ Paritas } & \multicolumn{4}{|c|}{ Kategori Ibu } & \multicolumn{2}{|c|}{ Total } & \multirow{3}{*}{$p$ value } & \multirow{3}{*}{ OR $(95 \% \mathrm{CI})$} \\
\hline & \multicolumn{2}{|c|}{$\begin{array}{c}\text { Secsio } \\
\text { Caesarea } \\
\end{array}$} & \multicolumn{2}{|c|}{$\begin{array}{c}\text { Tidak Secsio } \\
\text { Ceasarea }\end{array}$} & \multirow[t]{2}{*}{$\mathrm{n}$} & \multirow[t]{2}{*}{$\%$} & & \\
\hline & $\mathrm{n}$ & $\%$ & $\mathrm{n}$ & $\%$ & & & & \\
\hline Beresiko & 60 & 95.2 & 3 & 4.8 & 63 & 19.9 & 0,0000 & $5,657(1.709-18.722)$ \\
\hline Tidak Beresiko & 198 & 78 & 56 & 22 & 254 & 80.1 & & \\
\hline Total & 258 & 81.4 & 59 & 18.6 & 317 & 100 & & \\
\hline
\end{tabular}

Berdasarkan tabel 11, diketahui ibu yang memiliki paritas berisiko 95,2\% melahirkan SC, dan yang tidak secara SC hanya $4,8 \%$.

Terdapat hubungan signifikan antara ibu yang memiliki paritas beresiko memiliki risiko melahirkan secara SC 5,567 kali lebih besar dibandingkan dengan ibu yang tidak paritas dengan SC di RS Imanuel Bandar Lampung tahun 2014 dengan $\mathrm{OR}=5,567$, berarti

\section{d. Berdasarkan Jarak Kehamilan}

Tabel 12. Hubungan Jarak Kehamilan dengan Persalinan SC

\begin{tabular}{|c|c|c|c|c|c|c|c|}
\hline \multirow{3}{*}{ Jarak Kehamilan } & \multicolumn{4}{|c|}{ Kategori Ibu } & \multicolumn{2}{|c|}{ Total } & \multirow{3}{*}{$p$ value } \\
\hline & \multicolumn{2}{|c|}{$\begin{array}{c}\text { Secsio } \\
\text { Caesarea } \\
\end{array}$} & \multicolumn{2}{|c|}{$\begin{array}{c}\text { Tdk Secsio } \\
\text { Caeserea }\end{array}$} & \multirow[t]{2}{*}{$\mathrm{n}$} & \multirow[t]{2}{*}{$\%$} & \\
\hline & $\mathrm{n}$ & $\%$ & $\mathrm{n}$ & $\%$ & & & \\
\hline Berisiko & 146 & 80.7 & 35 & 19.3 & 181 & 57.1 & 0,813 \\
\hline Tidak Berisiko & 112 & 82.4 & 24 & 17.6 & 136 & 42.9 & \\
\hline Total & 258 & 81.2 & 59 & 18,8 & 317 & 100 & \\
\hline
\end{tabular}

Berdasarkan tabel di atas diketahui ibu yang memiliki jarak kehamilan berisiko melahirkan secara SC sebanyak $80,7 \%$, dan yang berisiko. tidak secara SC 19,3\%.

\section{e. Berdasarkan Berat Janin}

Tabel 13. Hubungan Berat Janin dengan Persalinan SC Berdasarkan Jarak Kehamilan

\begin{tabular}{|c|c|c|c|c|c|c|c|c|}
\hline \multirow{3}{*}{ Berat Janin } & \multicolumn{4}{|c|}{ Kategori Janin } & \multicolumn{2}{|c|}{ Total } & \multirow{3}{*}{$p$ value } & \multirow{3}{*}{ OR $(95 \% \mathrm{CI})$} \\
\hline & \multicolumn{2}{|c|}{$\begin{array}{c}\text { Secsio } \\
\text { Caesarea }\end{array}$} & \multicolumn{2}{|c|}{$\begin{array}{c}\text { Tidak Secsio } \\
\text { Caesrea }\end{array}$} & \multirow[t]{2}{*}{$\mathrm{n}$} & \multirow[t]{2}{*}{$\%$} & & \\
\hline & $\mathrm{n}$ & $\%$ & $\mathrm{n}$ & $\%$ & & & & \\
\hline Beresiko & 79 & 97.5 & 2 & 2.5 & 81 & 25.6 & 0,000 & $12.578(2.996-52.805)$ \\
\hline Tidak Beresiko & 179 & 78 & 57 & 22 & 236 & 74.4 & & \\
\hline Total & 258 & 81.4 & 59 & 18.6 & 317 & 100 & & \\
\hline
\end{tabular}

Berdasarkan tabel di atas diketahui ibu yang memiliki berat janin dalam kategori berisiko, dan bersalin secara SC sebanyak 97,5\%, dan yang tidak SC 2,5\%.

Terdapat hubungan signifikan antara berat janin yang berisiko dengan persalinan SC di RS
Tidak ada hubungan yang signifikan antara jarak kehamilan dengan persalinan SC di RS Imanuel Bandar Lampung tahun 2014.
Imanuel Bandar Lampung tahun 2014 dengan $\mathrm{OR}=12.578$, berarti ibu yang memiliki berat janin dalam kategori berisiko memiliki risiko bersalin SC 12.678 kali lebih besar dibandingkan dengan yang berat janinnya dalam kategori tidak berisiko. 


\section{f. Berdasarkan Letak Janin}

Tabel 14. Hubungan Letak Janin dengan Persalinan SC

\begin{tabular}{|c|c|c|c|c|c|c|c|}
\hline \multirow{3}{*}{ Letak Janin } & \multicolumn{4}{|c|}{ Kategori Janin } & \multicolumn{2}{|c|}{ Total } & \multirow{3}{*}{$p$ value } \\
\hline & \multicolumn{2}{|c|}{ Secsio Caesarea } & \multicolumn{2}{|c|}{$\begin{array}{c}\text { Tidak Secsio } \\
\text { Caesrea }\end{array}$} & \multirow[t]{2}{*}{$\mathrm{n}$} & \multirow[t]{2}{*}{$\%$} & \\
\hline & $\mathrm{n}$ & $\%$ & $\mathrm{n}$ & $\%$ & & & \\
\hline $\begin{array}{l}\text { Tdk Letak Belakang } \\
\text { Kepala }\end{array}$ & 49 & 89.1 & 6 & 2.5 & 55 & 17.4 & \\
\hline Letak Belakang Kepala & 209 & 79.8 & 53 & 22 & 262 & 82.6 & 0,154 \\
\hline Total & 258 & 81.4 & 59 & 18.6 & 317 & 100 & \\
\hline
\end{tabular}

Berdasarkan tabel 14, diketahui ibu yang memilikiletak janin tidak letak belakang kepala dan melahirkan secara SC adalah $89,1 \%$ dan yang tidak secara SC $2,5 \%$.

\section{g. Berdasarkan Letak Plasenta}

Tabel 15. Hubungan Letak Plasenta dengan Persalinan SC

\begin{tabular}{|c|c|c|c|c|c|c|c|c|}
\hline \multirow{3}{*}{ Letak Plasenta } & \multicolumn{4}{|c|}{ Kategori Janin } & \multicolumn{2}{|c|}{ Total } & \multirow{3}{*}{$p$ value } & \multirow{3}{*}{ OR $(95 \% \mathrm{CI})$} \\
\hline & \multicolumn{2}{|c|}{$\begin{array}{c}\text { Secsio } \\
\text { Caesarea }\end{array}$} & \multicolumn{2}{|c|}{$\begin{array}{c}\text { Tidak Secsio } \\
\text { Caesarea }\end{array}$} & \multirow[t]{2}{*}{$\mathrm{n}$} & \multirow[t]{2}{*}{$\%$} & & \\
\hline & $\mathrm{n}$ & $\%$ & $\mathrm{n}$ & $\%$ & & & & \\
\hline Beresiko & 52 & 94.5 & 3 & 2.5 & 55 & 17.4 & 0,000 & $4.712(1.418-15.655)$ \\
\hline Tidak Beresiko & 206 & 78.6 & 56 & 21.4 & 262 & 82.6 & & \\
\hline Total & 258 & 81.4 & 59 & 18.6 & 317 & 100 & & \\
\hline
\end{tabular}

Berdasarkan tabel 15, dapat diketahui bahwa ibu yang memiliki janin dengan letak plasenta berisiko dan bersalin secara SC lebih banyak $(94,5 \%)$ dibandingkan dengan yang bersalin tidak secara SC (2,5\%).

Terdapat hubungan signifikan antara letak plasenta yang berisiko dengan persalinan SC di RS Imanuel Bandar Lampung tahun 2014, OR= 4,712 berarti ibu yang memiliki janin dengan letak plasenta berisiko memiliki risiko melahirkan secara SC 4,712 kali lebih besar dibandingkan dengan yang letak plasentanya tidak berisiko.

\section{PEMBAHASAN}

\section{a. Persalinan Secsio Caesarea}

Diketahui dari 317 (100\%) total persalinan yang ada pada ibu bersalin di RS Imanuel Bandar Lampung pada tahun 2014.Yang mengalami SC sebanyak 258 $(81,4 \%)$. Hal ini tidak sesuai dengan standar WHO standar operasi SC disebuah negara pertahun adalah $5-11 \%$ dan secara nasional
Tidak ada hubungan yang signifikan antara berat janin dengan persalinan SC di RS Imanuel Bandar Lampung tahun 2014. presentasi operasi SC sekitar 5\% sementara untuk RS swasta bisa mencapai lebih dari $30 \%$.

Angka persalinan secara SC $81,4 \%$ di RS Imanuel Bandar Lampung tahun 2014, ini dapat terjadi karena komplikasi persalinan yang berhubungan dengan faktor ibu sehingga untuk menyelamatkan ibu dan bayi harus dilakukan tindakan SC dan ada juga ibu yang tidak ada komplikasi namun mengalami SC hal ini atas dasar permintaan ibu untuk melakukan tindakan $\mathrm{SC}$.

\section{b. Hubungan Faktor Usia Ibu dengan SC}

Hasil uji statistik chi-square menunjukkan ada hubungan signifikan antara usia ibu dengan SC di RS Imanuel Bandar Lampung tahun 2014 dengan $\mathrm{OR}=2,502$.

Sesuai dengan teori Prawiroharjo (2010), pada usia kurang dari 20 tahun organ-organ reproduksi tidak dapat berproduksi secara sempurna sehingga bisa terjadi kehamilan dan persalinan akan lebih mudah mengalami komplikasi yang dapat mengakibatkan persalinan SC. Selain itu kekuatan otot peritonium dan otot perut belum bekerja secara optimal sehingga 
sering terjadi persalinan lama yang memerlukan tindakan seperti SC.

Ibu hamil berumur muda juga memiliki kecenderungan perkembangan kejiwaanya belum matang sehinga belum siap menjadi ibu dan menerima kehamilanya, hal ini dapat berakibat terjadinya komplikasi obstetri yang dapat meningkatkan angka kematian ibu dan perinatal. Faktor resiko untuk melahirkan sulit pada ibu yang belum perna melahirkan pada kelompok umur dibawah 20 tahun dan pada kelompok diatas 35 tahun adalah 3 kali lebih tinggi dari kelompok umur reproduksi sehat 20-35 tahun.

Menurut analisa peneliti, persalinan yang sebagian besar mengalami SC 258 (81.4\%) di RS Imanuel Bandar Lampung karena pada saat ini banyak wanita yang melakukan hubungan seks diluar nikah sehingga terjadi kehamilan pertama dibawah usia 20 tahun dan banyak pula wanita yang mengejar karir sehingga kehamilan pertama pada usia diatas 30 tahun sehingga beresiko tinggi untuk ibu dan bayi perlu dilakukan SC.

Pada kategori usia ibu yang beresiko tetapi tidak mengalami SC sebanyak $7 \quad(9,7 \%)$ peneliti berpendapat ibu yang beresiko tapi dapat melahirkan secara normal karena ibu masih punya kekuatan HIS yang cukup, kontraksi otototot perut yang baik, sehingga mampu mendorong janin keluar secara normal tanpa melakukan tindakan SC.

Pada kategori usia ibu yang tidak beresiko tetapi mengalami SC sebanyak $193 \quad(74,8 \%)$ peneliti berpendapat hal ini atas dasar permintaan ibu untuk melakukan tindakan SC, hal ini dikarenakan kondisi ibu yang memiliki kecenderungan perkembangan kejiwaan yang belum matang sehingga ibu belum siap merasakan rasa sakit pada saat persalinan secara normal.

\section{c. Hubungan Faktor Ketuban Pecah Dini (KPD) dengan SC}

Hasil uji statistik chi square p-value $<\alpha$ yaitu $0,048<0,05$ dengan demikian ada hubungan signifikan antara KPD dengan SC di RS Imanuel Bandar Lampung pada tahun 2014 dengan $\mathrm{OR}=2,451$.

Rukiyah, Ai Yeyeh (2010), menyatakan ketuban pecah dini (KPD) adalah pecahnya ketuban sebelum waktunya melahirkan, hal ini dapat terjadi pada akhir kehamilan maupun jauh dari sebelum waktunya melahirkan.

KPD disebabkan oleh karena kontraksi uterus dan peregangan berulang, selaput ketuban pecah karena pada daerah tertentu terjadi perubahan biokimia yang menyebabkan selaput ketuban inferior rapuh ini lah yang dapat menyebabkan terjadinya persalinan SC. Resiko infeksi ibu dan bayi meningkat pada KPD, yang dapat meningkatkan inseden SC ataupun gagal persalinan normal (Prawiroharjo, 2010). Penelitian setianingrum (2008), menunjukan adanya hubungan signifikan antara SC dengan KPD.

Menurut analisa peneliti pada kategori ibu yang mengalami KPD dengan SC dengan $64 \mathrm{Ibu}$ ternyata mengalami KPD sebelum waktu melahirkan, hal ini dapat terjadi pada akhir kehamilan maupun jauh sebelum waktunya melahirkan pada keadaan ini harus segera dilakukan SC sebelum janin terinfeksi. Ibu yang mengalami KPD memiliki kejiwaan yang belum matang sehingga ibu belum siap merasakan rasa sakit pada saat persalinan secara normal.

Pada kategori KPD, ibu yang mengalami KPD tetapi tidak SC sebanyak 7, hal ini disebabkan karena kekuatan his pada ibu.

Pada kategori ibu yang tidak mengalami KPD tetapi mengalami SC (194) hal ini dikarenakan atas permintaan ibu untuk melakukan tindakan SC, hal ini dikarenakan kejiwaan yang belum matang sehingga ibu belum siap merasakan rasa sakit pada saat persalinan secara normal.

\section{d. Hubungan Faktor Paritas dengan SC}

Hasil uji statistik menunjukkan ada hubungan signifikan antara paritas dengan SC di RS Imanuel Bandar Lampung pada tahun 2014, $\mathrm{OR}=5,567$

Prawirohardjo (2010), Paritas adalah jumlah anak yang telah dilahirkan seorang wanita dalam keadaan hidup maupun mati selain itu juga paritas merupakan keadaan wanita yang berkaitan dengan jumlah anak yang dilahirkan, paritas juga merupakan salah satu faktor yang mempengaruhi persalinan secara SC, paritas faktor yang berpengaruh terhadap hasil konsepsi.

Klasifikasi Paritas antara lain Primipara, yaitu seorang wanita yang telah melahirkan seorang anak yang cukup besar untuk hidup didunia luar. Tanpa mengingat janinya hidup atau mati pada saat lahir. kematian maternal dibawah usia 20 tahun (primi muda beresiko) ternyata 2 sampai 5 kali lebih tinggi untuk terjadinya tindakan SC karena mempengaruhi His menyebabkan meningkatnya SC oleh karena kemajuan persalinan yang gagal dan kematian maternal juga meningkat pada usia diatas 30 tahun (primi tua beresiko) karena usia tua mengalami penyulit kehamilan yang tinggi seperti kematian maternal, preeklamsia, eklamsia, 
diabetes gestasional, plasenta previa, sulosio plasenta, pendarahan post partum dan yang lainya.

Sedangkan multipara (2 anak atau lebih ) pada usia kehamilan yang produktif (20 sampai 30) tahun paling aman di tinjau dari sudut kematian maternal. Resiko pada primipara muda beresiko dengan primipara tua beresiko dapat di tangani dengan asuhan obsetrik lebih baik yaitu tindakan bedah SC. Berikutnya adalah Multipara, yaitu seorang wanita yang telah pernah melahirkan anak hidup beberapa kali, dimana persalinan tersebut tidak lebih dari lima kali .

Menurut analisa peneliti tentang paritas ibu primipara 57 dan ibu multipara 241, ibu primipara yang mengalami SC sebanyak 47 dikarenakan usia ibu dibawah 20 tahun (primi muda) yang dapat mempengaruhi intensitas HIS yang menyebabkan terjadinya $\mathrm{SC}$ dan pada primipara tua beresiko (30 tahun keatas) memiliki penyulit kehamilan yang tinggi seperti kematian maternal, preeklamsia, hipertensi dan kesakitan serta kematian perinatal.

Pada kategori paritas, ibu beresiko sebesar 63 yang mengalami SC sebanyak 60 hal ini dikarenakan multipara beresiko (berusia diatas 30 tahun) memiliki penyulit kehamilan yang tinggi seperti preeklamsia, hipertensi dan kesakitan serta kematian perinatal.

Pada kategori beresiko yang tidak SC sebanyak 3 hal ini dikarenakan usia ibu masuk didalam usia produktif dan ibu tidak masuk dalam golongan multipara beresiko.

\section{e. Hubungan Jarak Kehamilan dengan SC}

Hasil uji statistik menunjukkan tidak ada hubungan signifikan antara jarak kehamilan dengan SC di RS Imanuel Bandar Lampung pada tahun 2014.

Jarak kehamilan adalah suatu pertimbangan untuk menentukan kehamilan yang pertama dengan kehamilan berikutnya (Depkes RI, 2000). Secara medis, rahim sebenarnya sudah siap untuk hamil kembali 3 bulan setelah melahirkan. Namun berdasarkan catatan statistik penelitian bahwa jarak kelahiran yang aman antara anak satu dengan lainya adalah 27 sampai 32 bulan. Pada jarak ini ibu akan memiliki bayi yang sehat serta selamat saat melewati proses kehamilan (Salmah,2006)

Seorang wanita setelah melahirkan membutuhkan dua sampai tiga tahun untuk memulihkan tubuhnya dan mempersiapkan dirinya pada persalinan berikutnya serta memberi kesempatan pada luka untuk sembuh dengan baik bila jarak terlalu pendek maka tindakan SC yang harus diambil karena jarak persalinan yang pendek akan meningkatkan resiko terhadap ibu dan anak (Mochtar, 2000). Hal ini disebabkan karena bentuk dan fungsi organ reproduksi belum kembali dengan sempurna sehingga fungsinya akan terganggu apabila terjadi kehamilan dan persalinan kembali. Jarak antara dua persalinan yang terlalu dekat menyebabkan meningkatnya anemia yang dapat menyebabkan BBLR, kelahiran preterm, dan lahir mati, yang mempengaruhi proses persalinan dan faktor bayi (Kusumawati, 2010).

Jarak kehamilan yang terlalu jauh berhubungan dengan bertambahnya umur ibu. Hal ini akan terjadi proses degeneratif, melemahnya kekuatan fungsi-fungsi otot uterus dan otot panggul yang menyebabkan kekuatan his tidak adekuat sehingga banyak terjadi partus lama yang mengakibatkan perlunya tindakan SC (Winkjosastro, 2005)

Diketahui dari $317(100 \%)$ persalinan di RS Imanuel Bandar Lampung tahun 2014. Pada kategori jarak kehamilan ibu yang beresiko sebanyak 181(50,7\%) dan ibu yang beresiko tidak SC sebanyak $136(42,9 \%)$. Hasil uji statistik tidak ada hubungan yang signifikan antara jarak kehamilan dengan SC di RS Imanuel Bandar Lampung Tahun 2014.

Menurut analisa peneliti hubungan faktor ibu dengan kejadian SC di RS Imanuel Bandar Lampung tahun 2014, seperti tabel 12 dari 317 persalinan yang sebagian besar jarak kehamilan ibu yang mengalami jarak kehamilan tidak beresiko sebanyak $112(82,4 \%)$ karena ibu sudah pernah melakukan SC pada persalinan pertamanya.

\section{f. Hubungan Berat Janin dengan Persalinan SC}

Diketahui bahwa dari 317 persalinan yang ada di RS Imanuel Bandar Lampung tahun 2014. pada kategori berat janin beresiko dengan SC sebanyak $79(97.5 \%)$ dan ibu yang bereiko tidak SC sebanyak $2(2.5 \%)$.

Hasil penelitian ini sesuai dengan teori Manuaba, bahwa pada keadaan berat janin yang besar menyebabkan janin sukar melewati jalan lahir karena kepala yang besar tidak dapat melewati panggul serta bahu yang lebar sulit melalui rongga panggul sehingga tindakan SC yang dilakukan, untuk mencegah terjadinya distosia bahu dan asfiksia yang dapat mempengaruhi kehidupan bayi selanjutnya. 


\section{g. Hubungan Letak Janin dengan Persalinan SC}

Diketahui bahwa persalinan yang masuk kategori berat janin yang letak belakang kepala dengan SC sebanyak $209(79 \%)$ dan ibu yang beresiko tidak SC sebanyak 53 (20.2\%).

Pada penelitian ini tidak sesuai dengan teori Manuaba, bahwa posisi dalam kondisi sungsang atau mellintang serta kelainan letak janin menyebabkan bayi tidak dapat melewati panggul dengan normal, sehingga tindakan SC menjadi alternaitf persalinan.

Dalam keadaan normal pada ibu bersalin di RS Imanuel indikasi untuk melakukan persalinan

\section{DAFTAR PUSTAKA}

Benson, P dan Pernoll. 2009. Buku saku Obstetry Gynecology William. Jakarta: EGC

Badan Penelitian dan Pengembangan Kesehatan, Kementerian Kesehatan Republik Indonesia. 2013. Riset Kesehatan Dasar 2013. Jakarta.

Chamberlain \& Peel. 2011. ABC Asuhan Persalinan. Jakarta: Penerbit Buku Kedokteran, EGC.

Departeman Kesehatan RI. 2000. Pedoman Pemantauan Wilayah Setempat Kesehatan Ibu, dan Anak (PWS-KIA). Jakarta: Depkes RI.

Depkes 2000. Pedoman Kesehatan Ibu dan Anak. Jakarta.

Dinas Kesehatan Provinsi Lampung Tahun 2012, Bidang Kesehatan Ibu dan Anak Tahun 2012. Dinas Kesehatan Provinsi Lampung.

Dinas Kesehatan Provinsi Lampung. 2013. Profil Dinas Kesehatan Provinsi Lampung Tahun 2013 di unduh di www.translate.com/english/pada-tahun2013-ini-dinas-kesehatan-provinsilampung-akan-melanjutkan-programunggulan-gubernur-lam/9953864.

Dinas Kesehatan Provinsi Lampung. 2012. Profil Dinas Kesehatan Provinsi Lampung Tahun 2012. Bandar Lampung.

Farrel, B., \& Puchalski, C.M. 2010. Evaluation of the FICA Tool for Spiritual Assessment. Journal of Pain and Symto Management, Vol. 40, No.2 Diakses 13 Maret 2015.

Indiarti. 2011. Panduan Lengkap Kehamilan, Persalinan dan Perawatan Bayi. Jogyakarta: Jogyakarta Publishing
SC tetap tinggi, menurut analisa peneliti masih banyak ibu yang melaksanakan persalinan SC karena social, tidak ingin merasakan sakit pada proses persalinan, nyeri pada proses inpartu dan sebagainya.

\section{SIMPULAN}

Ada hubungan signifkan antara usia ibu, KPD, paritas, berat janin dan letak plasenta dengan persalinan SC dan tidak ada hubungan yang signifikan antara jarak kehamilan dan letak janin dengan persalinan SC di RS Imanuel Bandar Lampung tahun 2014.

Kusumawati. 2010. Fakor-Faktor Resiko Yang Berpengaruh Terhadap Persalinan dengan Tindakan. Tesis diterbitkan di Semarang: Program Pasca Sarjana Universitas Dipenogoro.

Kusumawati F. 2010. Buku Ajar Keperawatan. Jakarta; Salemba Medika.

Manuaba. 2005. Ilmu kebidanan penyakit kandungan dan keluarga berencana untuk pendidikan bidan Jakarta: EGC.

Prawirohardjo, S. 2010. Ilmu Kebidanan (Edisi IV). Jakarta: Bina Pustaka.

Prawirohardjo, Sarwono. 2010. Ilmu Kebidanan. Jakarta. PT Bina Pustaka Sarwno Prawirohadjo.

Sadiman dan M. Ridwan. 2010. Faktor-Faktor yang Berhubungan dengan Persalinan Seksio Caesaria di RSUD Ahmad Yani Metro Tahun 2008. Jurnal Kesehatan "Metro Sai Wawai". Vol. II No. 2: 1-10.

Survei Demografi dan Kesehatan Indonesia. 2012 diunduh di http://www.bkkbn.go.id/litbang/pusdu/Has il\%20Penelitian/SDKI\%202012/Laporan\% 20Pendahuluan\%20SDKI\%202012.pdf.

Salmah, dkk. 2006. Asuhan kebidanan antenatal. Jakarta: EGC

Rukiyah, Ai Yeyeh \& Lia Yulianti. 2010. Asuhan Kebidanan IV (Patologi Kebidanan). Jakarta: Trans Info Media.

Winkjosastro. 2005. Ilmu Bedah Kebidanan. Jakarta: Yayasan Bina Pustaka Sarwono Prawirohardjo

WHO. 2011. Global Survei on Maternal and Perinatal Health. 